Vol.45, n. 3 : pp. 317-324, September 2002

ISSN 1516-8913 Printed in Brazil

\title{
Reproductive Strategies of Plagioscion squamosissimus Heckel, 1840 (Osteichthyes Sciaenidae) in the Itaipu Reservoir, Brazil
}

\author{
Regina Cintia Carnelós and Evanilde Benedito-Cecilio* \\ Universidade Estadual de Maringá; Department of Biology/NUPELIA; Av. Colombo, 5790; 87020-900; Maringá - \\ PR - Brazil
}

\begin{abstract}
Plagioscion squamosissimus is a dominant species in the Itaipu reservoir and has a significant role in the regional economy. The aim of the present research was the investigation of the curvina's reproductive strategies during the first years of the Itaipu reservoir (November 1983 to October 1989). Collections were undertaken from eleven sampling sites in the reservoir area, left bank tributaries, Paraná River and its tributaries. Species begin the reproduction in the area of influence of the Itaipu reservoir only in 1986. Size of early maturation, local and period of spawning showed gradual variations, with a broadening trend of this activity in the area, and thus guaranteeing success of the species. Mean size of early sexual maturation for the Plagioscion squamosissimus reached $16.2 \mathrm{~cm}$ for males and $17.8 \mathrm{~cm}$ for females.
\end{abstract}

Key words: Reproduction, Itaipu reservoir, Plagioscion squamosissimus, impact

\section{INTRODUCTION}

Reproductive strategies are a set of characteristics of a specie so that success in reproduction occurs through its descendents that guaran tee the maintenance of the population. Reproduction strategies comprise age or size of early sexual maturation, fecundity, size and type of gametes, period and local of spawning, reproductive behavior, type of oocyte development and sexual proportion. Reproductive tactics are variable characteristics of standard type and a response to fluctuations in the environment. Variability of strategy-shaping tactic adopted by species or population is essential for the success of generation or cohort as a result of sp awning. This is the reason why their structure and abundance may not be maintained by means of the recruitment of new individuals (Vazzoler, 1996). Potts and Wootton (1989), however, stated that one of the challenges for the ecologist is to show how strategy and reproductive tactics are adaptable in certain environmental circumstances. Interception of watercourses by damming changes drastically the dynamics of the natural system, so new ecological conditions are established. Fish species will respond to such pressure by the evolution of compromising adaptations to the new environment. If this fails to happen, they will disappear or their population will decrease significantly. The establishment of reproduction strategies, adequate to the new environment, wi 11 determine the success of the species (Agostinho et al., 1999).

\footnotetext{
*Author for correspondence
} 
Plagioscion squamosissimus, commonly known as curvina, was introduced in reservoirs of the northeastern Brazil in the 40s and in the Pardo River (state of São Paulo, Brazil) in the 60s (Nomura, 1984). Currently species is widely distributed in South America and it's one of the dominant species in the Itaipu reservoir which maintains a high contribution in fisheries (Agostinho, 1994; Benedito-Cecilio, 1994).

The present research work investigated the reproductive strategies of the Plagioscion squamosissimus in the early years of the Itaipu reservoir. These informations are indispensable data to the understanding of the auto-ecology of the species and fundamental for the management this fishery resource.

\section{MATERIALS AND METHODS}

Between November 1983 and October 1989, eleven sampling sites were established: three stations in the Itaipu reservoir (municipalities of Guaíra - GUAI; Santa Helena - SHEL; Foz do Iguaçu - FOZ); four in the left bank tributaries (Ocoí River - OCOI; São Francisco Falso River SFFA; São Francisco Verdadeiro River - SFVE; Arroio Guaçu River - GUAC); two in the Paraná River (one upstream - MONT; one downstream JUSA, the Itaipu reservoir); and two in tributaries of the Paraná River (Iguatemi River - IGUA; Piquiri River - PIQUI).

Fishing gear consisted of stationary nets with mesh sizes 3 to $16-\mathrm{cm}$ mesh nets between nonadjacent knots, set out for 24 hours at each sampling station. Standard length (Ls), total weight (Wt) a nd weight of gonads ( $\mathrm{Wg})$ were taken for each specimen. Gonads, sex and stages of gonadal maturity were identified for each and every individual by macroscopic inspection (Vazzoler, 1996).

Mean size at first sexual maturation (Lpm) in males and females was considered the size at which $50 \%$ of individuals began the reproductive process (Vazzoler, 1981). Evaluation of changes in size of species's entrance in reproduction activity was analyzed by standard average length for the three smallest individuals (males or females) captured in the gonadal maturation stage during the period in which investigation occurred (Sato and Godinho, 1988).

Relative contribution of gonadal weight $(\mathrm{Wg})$ in total weight $(\mathrm{Wt})$, or Gonadal Somatic
Relationship (GSR) of each individual was calculated by GSR $=\mathrm{Wg} / \mathrm{Wt} \times 100$, in which chief events of reproduction cycle were evaluated by graphs of seasonal variation of average GSR (Vazzoler, 1996). Applied to data in each sampling station, procedure was used to identify reproduction activity in distinct environments under analysis, while seasonal analysis determined the period of species reproduction.

\section{RESULTS}

During the period from November 1983 and October 1989 were caught 3,629 males and 3,258 females totaling 6,887 individuals. Analysis of mean size of the three smallest individuals, males and females with maturating gonads, show increase of standard mean length during the study period. However, in the last period lengths were higher than those recorded at the start of the research (Tab. 1).

Table 1 - Mean standard length $(\mathrm{cm})$ of the smallest three individuals, males and females of $P$. squamosissimus, per period (maximum standard length between parentheses).

\begin{tabular}{ccc}
\hline & Sex & \\
Periods & Males & Females \\
\hline $1983-84$ & $15,1(43,0)$ & $-(36,5)$ \\
$1984-85$ & $15,8(36,5)$ & $18,5(41,0)$ \\
$1985-86$ & $14,6(37,3)$ & $23,3(44,1)$ \\
$1986-87$ & $16,9(37,7)$ & $18,7(43,6)$ \\
$1987-88$ & $15,1(38,0)$ & $21,7(46,9)$ \\
$1988-89$ & $17,7(36,4)$ & $22,8(47,9)$ \\
\hline
\end{tabular}

The size of $50 \%$ of individuals of $P$. squamosissimus capable of reproduction was 16.2 $\mathrm{cm}$ for males and $17.8 \mathrm{~cm}$ for females. Whole population participated effectively in the reproductive process to $22.5 \mathrm{~cm}$ (Fig. 1).

Mean values for males and females of Gonadal Somatic Relationship for each sampling station and for each period analyzed are shown in Figures 2 and 3, respectively. During the first three years following the Itaipu reservoir formation no reproductive activity of species was recorded. It was only after 1986-87 that recorded the higher GSR values for both sexes, specially in OCOI and SFVE. In the period 1987-88, station SFFA presented high GSR values too. Within the principal body of the reservoir only FOZ showed increase of mean values of GSR. 


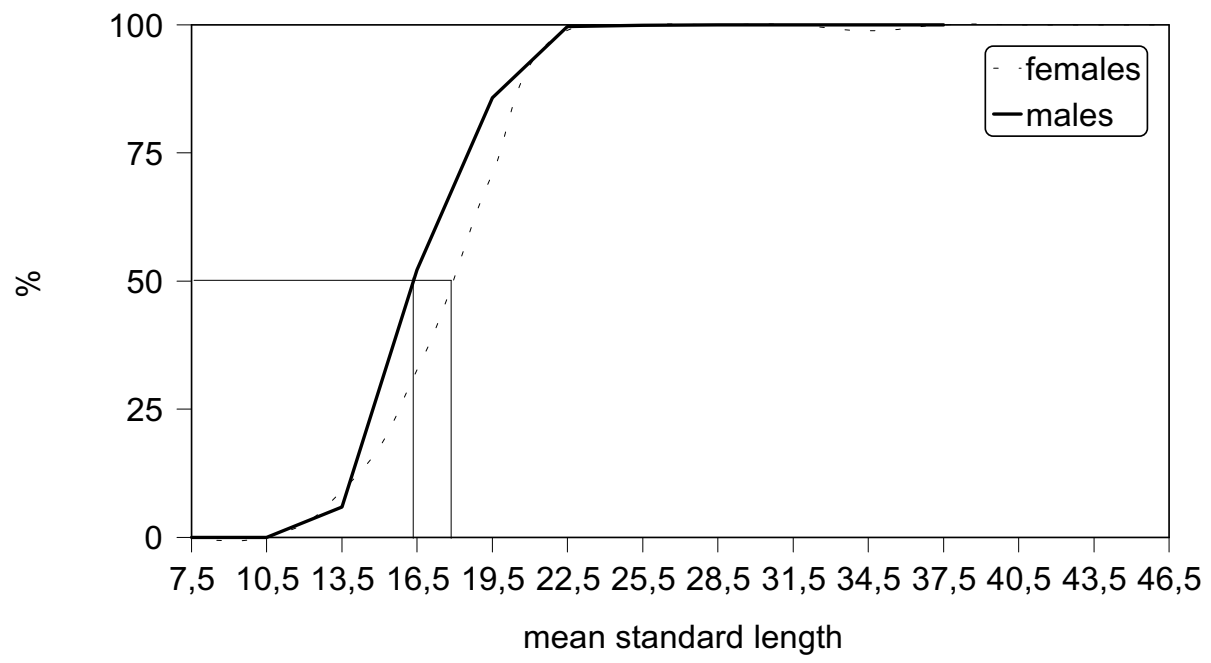

Figure 1 - Distribution of frequency of males and females of P. squamosissimus according to class of standard length.

These values doubled during 1988-89, the last period under analysis. Further, during the latter period reproduction area extended to the tributary GUAC.

Reproduction period of species extended itself from spring to autumn, with peaks in spring and summer (Tab. 1). It should be emphasized that GSR variations were perceived as from spring 1986. Mean values became gradually higher during the last periods under analysis.

\section{DISCUSSION}

Reproduction is one of the main events in the life history of the species (King, 1995). It is a more conservative item than all the other vital activities. Thus, it imposes limits to the colonization of reservoirs (Agostinho et al., 1999). In the case of $P$. squamosissimus the above supposition was confirmed since it was only in the spring of 1986 that the species had favorable conditions for spawning and development of young specimens and, consequently, a more thorough occupation of the flooded impounding. Nevertheless, the process involved displacements between areas in sea rch of specific sites favorable to spawning and to the development of the juveniles ("cradle areas").

In the reservoir the size of first gonadal maturation of the P. squamosissimus was bigger in females. The fact has been recorded for various teleosts (Geevarchese and John, 1983; Benedito, 1989; Vazzoler, 1991). However, the size was approximately the same for both sexes when $100 \%$ of the population was capable of reproduction. When minimum sizes of $P$. squamosissimus specimens in the maturation stage were a nalyzed, size fluctuations were recorded. In the last year of the period under analysis, it was higher than was the first. It has also been found that maximum standard length reached by the population in the last years of the period studied was greater tha $n$ that recorded immediately after impounding. This fact suggested an increase in species fecundity throughout the years, since there was a linear relationship in teleosts between body size and fecundity (Eenennaam and Doroshov, 1998).

Since effect of environmental changes on age and size of maturity depends on variations in growth and mortality rates (Wooton, 1990), limnological modifications by Itaipu impounding caused alterations in growth and mortality of species. This has consequently determined modifi cation in size of early maturation of $P$. squamosissimus. After the first three years a adaptation of the fish community occurred, carrying to successful of the specie (Agostinho et al., 1994; Benedito-Cecilio, 1994). In his study on Gymnotus carapo during two consecutive years, Barbieri (1981) recorded that the species reached first maturation with a greater size in the second year of study. The same author believes that this fact may have occurred owing to a significant increase in the reservoir's water level. 

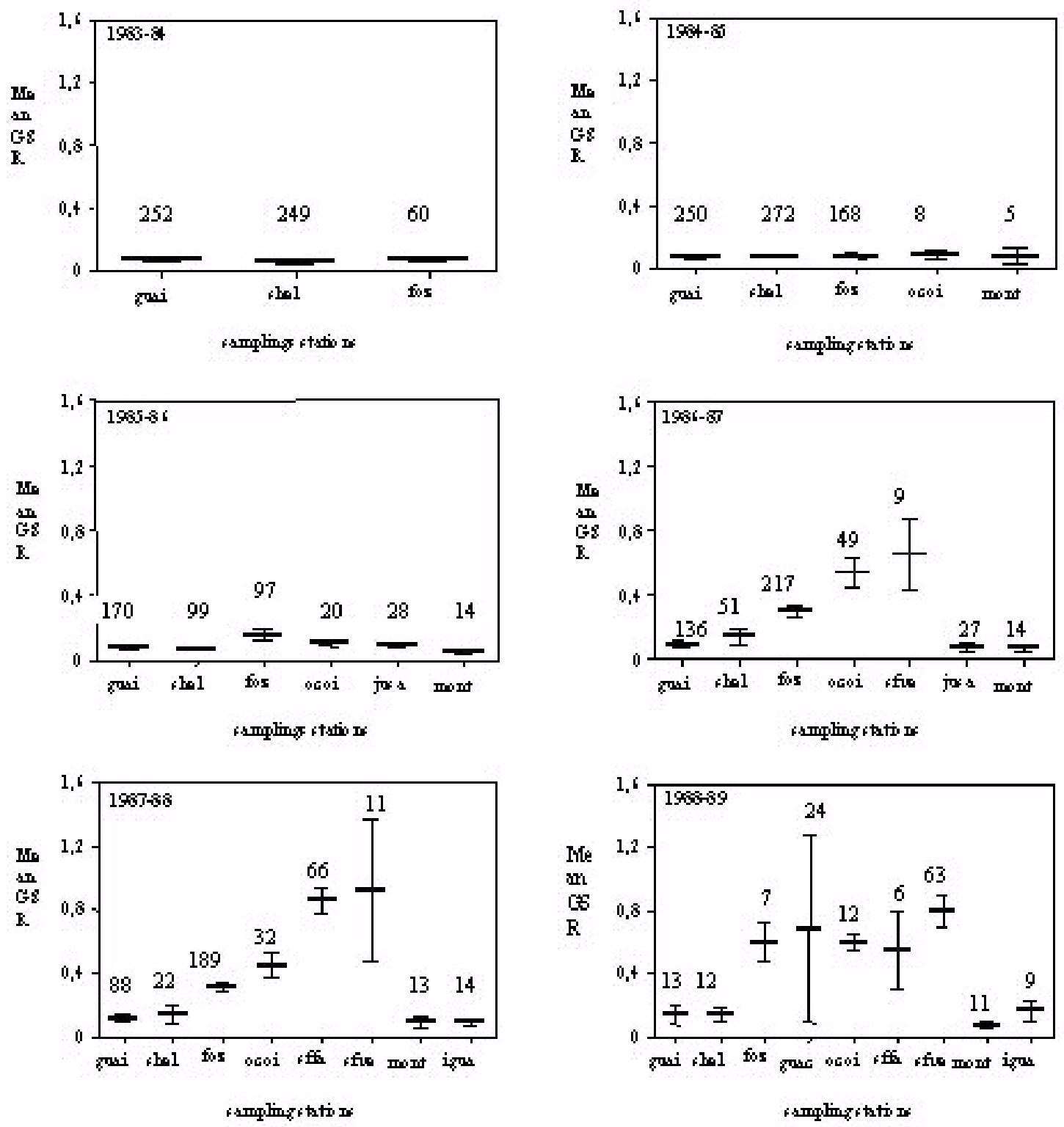

Figure 2 - Average values of Gonadal Somatic relationship (GSR) of P. squamosissimus males for each sampling station and period (internal horizontal line = mean GSR; vertical bar = confidence interval at $95 \%$; the number means individuals sampled). 

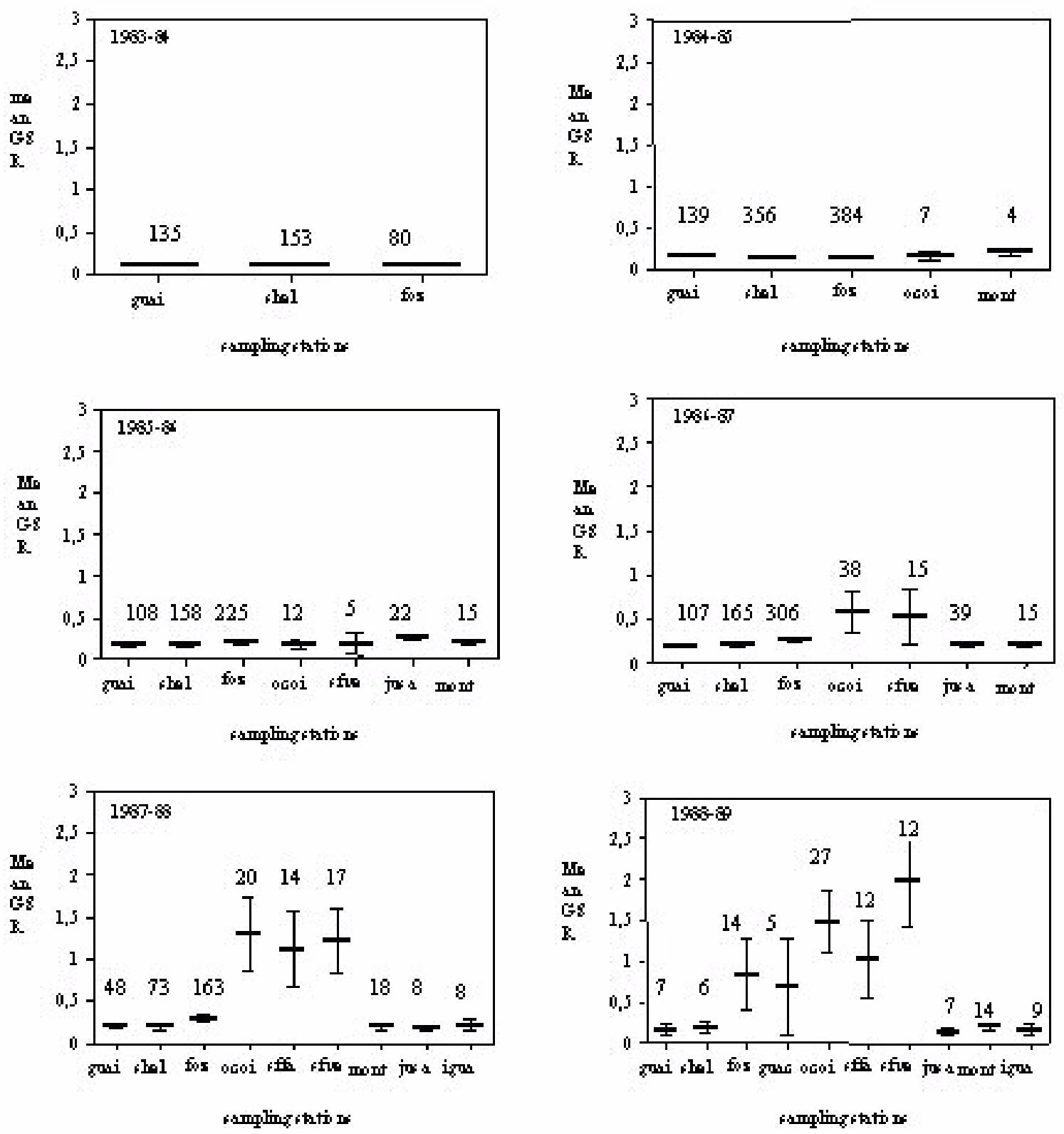

Figure 3 - Mean values of Gonadal Somatic Relationship (GSR) of P. squamosissimus females for each sampling station and period (internal horizontal line = mean GSR; vertical bar = confidence interval at $95 \%$; the number means individuals sampled). 
Table 2 - Mean values of Gonadal Somatic Relationship (GSR) and confidence interval at 95\% ( $t^{*} \mathrm{~s} 0$ ) for the period 1983 - 89 of P. squamosissimus males and females.

\begin{tabular}{lcccc}
\hline Seasons & $\mathbf{n}$ & $\mathbf{M a l e s}$ & \multicolumn{2}{c}{ females } \\
\hline Spring 83 & $\mathbf{R G S} \pm \mathbf{t}^{*} \mathbf{s} \mathbf{0}$ & $0,0916 \pm 0,0617$ & 12 & $0,1206 \pm 0,0774$ \\
Summer 83-84 & 306 & $0,0596 \pm 0,0651$ & 175 & $0,1131 \pm 0,0608$ \\
Autumn 84 & 149 & $0,0577 \pm 0,0354$ & 118 & $0,1206 \pm 0,0535$ \\
Winter 84 & 20 & $0,0606 \pm 0,0465$ & 16 & $0,1451 \pm 0,0614$ \\
Spring 84 & 62 & $0,0948 \pm 0,0609$ & 76 & $0,1426 \pm 0,0689$ \\
Summer 84-85 & 274 & $0,0828 \pm 0,0744$ & 388 & $0,1397 \pm 0,0590$ \\
Autumn 85 & 221 & $0,0609 \pm 0,0413$ & 303 & $0,1535 \pm 0,0557$ \\
Winter 85 & 28 & $0,0621 \pm 0,0294$ & 44 & $0,1818 \pm 0,0691$ \\
Spring 85 & 190 & $0,0644 \pm 0,0316$ & 66 & $0,1898 \pm 0,0316$ \\
Summer 85-86 & 168 & $0,0866 \pm 0,0619$ & 214 & $0,0866 \pm 0,0652$ \\
Autumn 86 & 32 & $0,0699 \pm 0,0333$ & 65 & $0,1804 \pm 0,0643$ \\
Winter 86 & 79 & $0,9509 \pm 0,1844$ & 115 & $0,1746 \pm 0,0701$ \\
Spring 86 & 194 & $0,1618 \pm 0,2320$ & 185 & $0,1699 \pm 0,0837$ \\
Summer 86-87 & 314 & $0,2610 \pm 0,2539$ & 444 & $0,2311 \pm 0,2421$ \\
Autumn 87 & 41 & $0,1804 \pm 0,2513$ & 78 & $0,2690 \pm 0,3468$ \\
Spring 87 & 9 & $0,1049 \pm 0,1451$ & 5 & $0,1504 \pm 0,0410$ \\
Winter 87 & 60 & $0,1913 \pm 0,2174$ & 91 & $0,2531 \pm 0,2391$ \\
Summer 87-88 & 323 & $0,4233 \pm 0,3584$ & 279 & $0,4086 \pm 0,5174$ \\
Autumn 88 & 29 & $0,0966 \pm 0,0967$ & 35 & $0,2557 \pm 0,3602$ \\
Spring 88 & 79 & $0,4414 \pm 0,3714$ & 32 & $1,0173 \pm 0,9815$ \\
Summer 88-89 & 189 & $0,5475 \pm 0,3768$ & 82 & $0,7342 \pm 0,7160$ \\
Autumn 89 & 3 & $0,8978 \pm 0,2915$ & 4 & $0,1351 \pm 0,0293$ \\
Winter 89 & - & - & 44 & $0,1818 \pm 0,0691$ \\
Spring 89 & - & - & 13 & $1,3563 \pm 1,1903$ \\
\hline
\end{tabular}

In the Itaipu reservoir the characteristics of the new environment reflected the complex interaction between the biotic and the abiotic components as a result of changes within the set of limnological variables which characterized impact on fish populations.

Although P. squamosissimus is distributed in all the reservoir's environments, GSR results indicate that reproduction preferentially occurs in the tributaries of the reservoir. This is corroborated by ichthyoplanctonic studies by Nakatani (1994) in the same environment. The author states that larvae, spawned in the tributaries, are carried to the reservoir and their development is completed therewith. Tributaries of the reservoir are characterized by low transparency and water temperature rates (Benedito-Cecilio, 1994). Nonetheless, upstream the reservoir and in the tributaries of the Paraná River, values of the GSR are low. It is supposed that small-sized lotic water bodies, in comparison to those of the Paraná River, are more favorable to the development of $P$. squamosissimus eggs and larvae.

Mean GSR results indicated that the reproduction of the of P. squamosissimus occurred from spring to autumn, with peaks in summer for males and in the spring for females. This was especially true for the last years of the studied period. Nakatani (1994) also recorded this broad spawning period for larvae, since $P$. squamosissimus larvae were found between November and June, with peaks in March and April. Environmental changes in impounding probably impeded the reproduction success in the early years. In the following years, when stabilization of environmental conditions was ratified, the curvina expanded its reproduction areas to the tributaries.

Reproductive strategies are generally adaptable to environmental conditions and consist of a response of the species or of the population to minimize energetic costs. In this work the size of first maturation, environmental and spawning period 
represented homeostatic responses of the species with regard to the environment towards a reduction of energy costs.

It is, thus, important to emphasize that the curvina had a wide feeding variability in the area of the Itaipu reservoir. During the same period, the species obtained a diet composed of approximately 30 species of fish, with Hypophthalmus edentatus and Roeboides paranensis as its main feeding items (Hahn, 1991; Hahn et al., 1998). In the first years following impounding Hypophthalmus edentatus had the highest captures per unit of effort (Benedito-Cecilio, 1994). This showed that easiness in food acquisition due to availability of prey decreased energy spending. Transfe rence of recourses to reproduction consequently increased the species's fitness in the environment.

On the other hand, diversity of prey caught by the predator and the latter's ability in changing its diet when prey availability changes influenced the stability of present populations and of the assemblage (Pianka, 1982). When reproduction aspects of the of $P$. squamosissimus during the first six years of the Itaipu reservoir were taken into account, reproduction tactics of the species underwent gradual chan ges because of biotic and abiotic conditions in the new environment. This fact reflected in the species's population success in the Itaipu reservoir. However, since $P$. squamosissimus is an introduced species, a follow up of the degree of interference of it s population on fish assemblage would be required. Further studies will help towards more efficient measures of correction and prevision of impact of this and other fish introductions in Brazilian rivers.

\section{ACKNOWLEDGEMENTS}

The authors would like to thank the Research Nucleus in Limnology, Ichthyology and Aquiculture (Nupelia) for its logistic support; librarian Maria Salete Ribelatto for bibliographical service; Dr Luiz Felipe Machado Velho for discussion of results and text revision; Dr. Thomas Bonnici and Milena Morimoto for the English translation of the manuscript.

\section{RESUMO}

Plagioscion squamosissimus, amplamente distribuída na América do Sul, constituiu-se no reservatório de Itaipu em uma das espécies dominantes e de expressiva participação nos desembarques comerciais. Com o intuito de investigar as estratégias reprodutivas utilizadas pela espécie nos primeiros anos de formação do reservatório de Itaipu foram realizadas coletas durante o período de novembro de 1983 a outubro de 1989 em onze estações de amostragens situadas na área do reservatório, tributários da margem esquerda, rio Paraná e seus tributários. Constatou se que a espécie iniciou o processo reprodutivo na área de influência o reservatório de Itaipu somente apartir de 1986. Após este período a estratégia reprodutiva exibida pela espécie foi adaptativa, sendo que o tamanho da primeira maturação, local e período de desova, apresentaram variações gradativas no sentido de ampliação desta atividade na área, garantindo o sucesso da espécie. $\mathrm{O}$ tamanho médio da primeira maturação sexual para a população de $P$. squamosissimus é de $16,2 \mathrm{~cm}$ para machos e de $17,8 \mathrm{~cm}$ para fêmeas.

\section{REFERENCES}

Agostinho, A. A. (1994), Considerações sobre a atuação do setor elétrico na preservação da fauna aquática e dos recursos pesqueiros. In- Seminário sobre fauna aquática e o setor elétrico brasileiro, Alpinópolis. pp. 13-22.

Agostinho, A. A. (1994), Considerações sobre a atuação do setor elétrico na preservação da fauna aquática e dos recursos pesqueiros. In- Reuniões Temáticas preparatórias. Cad. 4: Estudos e Levantamentos. Comase e Eletrobrás, Rio de Janeiro. $92 \mathrm{pp}$.

Agostinho, A. A.; Julio Jr., H. F. and Petrere Jr., M. (1994), Itaipu Reservoir (Brazil): impacts of the impoundment on the fish fauna and fisheries. InCowx, I. G. (ed.). Rehabilitation of freshwater fishes. Fishing News Book, Bodman, pp. 171-184.

Agostinho, A. A.; Miranda, L. E.; Bini, L. M.; Gomes, L. C.; Thomaz, S. M. and Suzuki, H. I. (1999), Patterns of colonization in Neotropical reservoirs and prognoses on aging. Theoretical Reservoir Ecology and its Applications. pp. 227-265.

Barbieri, M. C. (1981), Contribuição ao estudo da biologia de Gymnotus carapo (Linnaeus, 1758) na represa do Lobo, Estado de São Paulo (Pisces, Ostariophysi, Gymnotidae). PhD Thesis, Universidade Federal de São Carlos, São Carlos, Brasil. 
Benedito, E. (1989), Estrutura da População, Reprodução e Seletividade Amostral de Hypophthalmus edentatus. (Spix, 1829) (Osteichthyes, Siluriformes) no Reservatório de Itaipu - PR. M.Sc. Thesis, Universidade Federal do Paraná, Curitiba, Brazil.

Benedito-Cecilio, E (1994), Dominância, uso do ambiente e associações interespecíficas na ictiofauna do reservatório de Itaipu e alterações decorrentes do represamento. $\mathrm{PhD}$ Thesis, Universidade de São Carlos, São Carlos, Brasil.

Eenennaam, J. P. and Doroshov, S. I. (1998). Effects of age and body size on gonadal development of Atlantic sturgeon. Journal of Fish Biology, 53, 624-637.

Geevarchese, C. and John, P. A. (1983), Maturation and spawning of a Gobiid fish, Oligoleps acutipennis (Cuv. and Val.) from the Southwest coast of India. J. Fish. Biol., 23, 611-624.

Hahn, N. S. (1991), Alimentação e dinâmica da curvina Plagioscion squamosissimus (HECKEL, 1840) (Pisces, Perciformes) e aspectos da estrutura trófica da ictiofauna acompanhante do rio Paraná. $\mathrm{PhD}$ Thesis, Universidade Estadual Paulista, Rio Claro, Brasil.

Hahn, N. S.; Agostinho, A. A.; Gomes, L. C. and Bini, L. M. (1998), Estrutura trófica da ictiofauna do reservatório de Itaipu (Paraná-Brasil) nos primeiros anos de sua formação. Revista Interciência, 23, 299-305.

King, M. (1995), Fisheries Biology, Assessment and Management. Fishing News Books, Oxford. 341 pp.

Nakatani, K. (1994), Estudo do ictioplâncton no reservatório de Itaipu (Rio Paraná-Brasil): Levantamento das áreas de desova. $\mathrm{PhD}$ Thesis, Universidade Federal do Paraná, Curitiba, Brasil.
Nomura, H. (1984), Dicionário dos Peixes do Brasil. Brasília: Editerra. 482 pp. il.

Pianka, E. R. (1982), Ecologia Evolutiva. Barcelona : Omega, 1982. 365 pp.

Potts, G. W. and Wootton, R. J. (1989), Fish Reproduction: Strategies and Tactics. Academic Press, London.

Sato, Y. and Godinho, H. P. (1988), A questão do tamanho da primeira matruação dos peixes de Três Marias, MG. Paper presented at Associação Mineira de Aqüicultura. Brasília. pp. 93.

Vazzoler, A. E. A. (1981), Manual de métodos para estudos biológicos de populações de peixes: reprodução e crescimento. $\mathrm{CNPq} /$ Programa Nacional de Zoologia, Brasília.

Vazzoler, A. E. A.; Agostinho, A. A. and Suzuki, H. I. (1991), Estimativas de $L_{50}$ e $L_{100}$ para 80 espécies de teleósteos do Alto Rio Paraná. Paper presented at IX Encontro Brasileiro de Ictiologia, Maringá, Paraná. pp. 55.

Vazzoler, A. E. A. (1996), Biologia da reprodução de peixes teleósteos: teoria e prática. EDUEM, Maringá.

Wootton, R. J. (1990), Ecology of Teleost Fishes. Chapman and Hall, London.

Received: June 26, 2000;

Revised: June 28, 2001; Accepted: November 21, 2001. 